
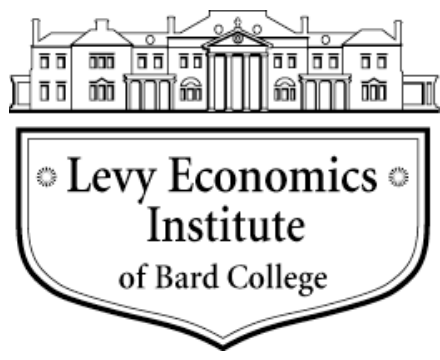

Working Paper No. 874

\title{
"Engendering" Intergovernmental Transfers: Is There a Case for Gender-sensitive Horizontal Fiscal Equalization?
}

by

\author{
Abhishek Anand* \\ Ministry of Finance, Government of India \\ Lekha S. Chakraborty** \\ Levy Economics Institute of Bard College
}

September 2016

This paper was invited for presentation at the 25th IAFFE Annual Conference on "Transitions and Transformations in Gender Equality," National University of Ireland Galway, June 24-26, 2016.

*Corresponding author: Room No. 250D, North Block, Department of Economic Affairs, Ministry of Finance, Government of India, Delhi, India. Tel.: +918375824268. E-mail: abhishek_anand444@yahoo.com.

**National Institute of Public Finance and Policy, 18/2 Satsang Vihar Marg, Special Institutional Area (Near JNU East Gate), A-17 Aruna Asafali Marg, New Delhi 110067, Delhi, India. E-mail: lekhachakraborty@gmail.com.

The Levy Economics Institute Working Paper Collection presents research in progress by Levy Institute scholars and conference participants. The purpose of the series is to disseminate ideas to and elicit comments from academics and professionals.

Levy Economics Institute of Bard College, founded in 1986, is a nonprofit, nonpartisan, independently funded research organization devoted to public service. Through scholarship and economic research it generates viable, effective public policy responses to important economic problems that profoundly affect the quality of life in the United States and abroad.

\author{
Levy Economics Institute \\ P.O. Box 5000 \\ Annandale-on-Hudson, NY 12504-5000 \\ http://www.levyinstitute.org
}

Copyright (C) Levy Economics Institute 2016 All rights reserved

ISSN 1547-366X 


\begin{abstract}
This paper seeks to evaluate whether a gender-sensitive formula for the inter se devolution of union taxes to the states makes the process more progressive. We have used the state-specific child sex ratio (the number of females per thousand males in the age group 0-6 years) as one of the criteria for the tax devolution. The composite devolution formula as constructed provides maximum rewards to the state with the most favorable child-sex ratio, and the rewards progressively decline along with the declining sex ratio. In this formulation, the state with the most unfavorable child-sex ratio is penalized the most in terms of its share in the horizontal devolution. It is observed that the inclusion of gender criteria makes the intergovernmental fiscal transfers formula more equitable across states. This is not surprising given the monotonic decline in the sex ratio in some of the most high-income states in India.
\end{abstract}

Keywords: Fiscal Devolution; Gender; Equity; Intergovernmental Transfers

JEL Classifications: E62, E63 
Against the backdrop of the Fourteenth Finance Commission, this paper aims to engage in a significant debate, highlighting the plausibility of incorporating gender into intergovernmental fiscal transfers. We also analyze if plugging gender into formula-based fiscal transfers is equitable. Chakraborty (2010) noted that given the disturbing demographics - the monotonous decline in the child sex ratio, especially in some of the prosperous states of India-there can be no valid objection to designing Finance Commission transfers for this purpose. The study noted that while social mores cannot be changed by fiscal fiats, particularly when prejudices run deep, a proactive approach by a high constitutional body like the Finance Commission is called for, especially when the prejudices are blatantly oppressive. Indeed, such action is imperative.

The intergovernmental transfer system can and should play a role in upholding the right to life for India's girl children. That being said, it needs to be mentioned that it is not plausible to incorporate more gender variables in the Finance Commission's already complex transfer formula. In other words, inclusion of a "gender inequality index" in the formula may not result in the intended results, as the variables included in the index may cancel one another out. This paper works out the plausibility of integrating the sex ratio as a distance variable. We will revisit this point later.

The paper is organized into five sections. Section 1 analyzes the intergovernmental fiscal mechanism in India with special reference to the Finance Commission and draws up a summary of the empirical literature. Section 2 deals with the critical analysis of the evolution of criteria of fiscal devolution in India, and examines the plausibility of incorporating gender in the devolution formula. Section 3 presents the distribution of the divisible pool of taxes among states with and without a gender variable. This section also presents the change in the ranks of the states in terms of allocation of revenue after integrating the gender variable. Section 4 econometrically analyzes whether the intergovernmental fiscal mechanism is regressive or progressive in India, and how the dynamics of regressivity/progressivity change after plugging gender variables into the devolution formula. Section 5 concludes. 


\section{THE INTERGOVERNMENTAL FISCAL MECHANISM IN INDIA: AN INSTITUTIONAL AND EMPIRICAL BACKGROUND}

Intergovernmental fiscal transfers are primarily for addressing the horizontal and vertical imbalances in fiscal federalism. Indian states, like all other federations, are also ridden by problems of horizontal and vertical imbalances. On the one hand, we have states (like Gujarat and Maharashtra) with sufficient revenue-raising resources, but on the other hand there are backward states (like Bihar and Odisha) with very minimal revenue resources at their disposal. In spite of the resource endowments, it is the responsibility of the states to provide its citizens a comparable standard of services. In the process of fulfilling these responsibilities, the states might incur expenditures that are disproportionate to their sources of revenue. To bridge this gap of finances across the states, and between states and the center, Article 280 of the Indian constitution establishes an institutional framework to facilitate transfers from the central government to the states. This body is the Finance Commission, which came into existence in 1951. The core mandate of the Finance Commission, as laid out in Article 280 of the constitution, is to make recommendations on "the distribution between the Union and the States of the net proceeds of taxes which are to be, or may be, divided between them." Since 1951, fourteen Finance Commissions have been assembled to submit their reports to the Union government.

The constitution of India provides independent revenue-raising and spending power to both the central and the state governments. However, the most productive sources of revenue belong to the central government, while the most expensive items of expenditure are with the states. The state governments are directly responsible for the maintenance of law and order and are charged with the responsibility of carrying on welfare activities, such as education, health care, etc. Consequently the states have less revenue income than they need. According to the Indian Public Finance Statistics, the relative share of the states in overall revenue generation was nearly was 41 percent, whereas their share in total expenditure was 53 percent. The objective of intergovernmental transfers is to offset the fiscal disability arising from the low revenue-raising capacity of the individual states and their higher unit cost for providing public services. 
A three-tier transfer mechanism exists in India. The central government transfers funds to the states in India via the Finance Commission and the Planning Commission, and also makes discretionary transfers through various union ministries and agencies.

\subsection{A Review of the Empirical Literature}

The empirical literature on intergovernmental fiscal transfers focuses more on the amount rather than the criteria of devolution and whether or not it produces an equalizing effect. The equity and efficiency dimensions of the criteria used in the Finance Commission transfers are an underresearched area. We will be analyzing the evolution of the criteria of each of the Finance Commissions in section 2 against the backdrop of efficiency and equity debates. This section quickly summarizes the existing empirical analyses on intergovernmental fiscal transfers in India.

Rao (2002) discusses the trends in fiscal imbalances and the sources of such imbalances in the states. He argues that reforms should be focused on imparting efficiency and improving the revenue productivity of states. However, studies show that the design of inter se fiscal devolution of union tax to the states has not done enough to help states augment their resource base.

Rao (2003) evaluates the transfers from the Finance Commission and concludes that incentivelinked transfers are too small to make any difference in fiscal performance. Chakraborty (2003) finds that the fiscal transfers by various Finance Commissions are regressive in nature, as the aggregate tax transfers per capita are positively related to the per capita income of the states. He also finds that though fiscal autonomy was found to be negatively related to grant transfersimplying progression in the transfer of grants - it failed to eliminate horizontal inequality, as the relative share of grants (especially fiscal equalization grants) is much less than the tax transfers.

Singh and Srinivasan (2006) examine India's federal system in the context of prospects for India's future economic growth and development. In their opinion, the transfer system in India is a complex one, with different channels of transfers, so it is impossible to draw a firm conclusion on the equalizing and growth-promoting impact of transfers. Singh (2004) argues that reducing 
the channels of intergovernmental transfers would help in achieving objectives of horizontal equity.

Nirmal (2004) analyzes the trend in the transfer of resources from the central government to the states from 25 years of data (i.e., from 1978-79 to 2002-03). He finds that although the amount of the transfer of resources from central government to states has increased in every five-year period, the rate of that increase has declined in each five-year period.

Garg, Goyal, and Pal (2014) empirically estimate the own tax capacity and tax effort ${ }^{1}$ of fourteen Indian states for the period 1992-2010. Their results indicate that the tax capacity is influenced not only by its tax base, but also by economic, demographic, infrastructural, and political variables, as well as an index for administration and governance and fiscal incentive variables. Coondoo et al. (2001) examines the relative tax performance of the states in India for the period 1986-87 to 1996-97 and found that the states in southern and western India display superior tax performance compared to the remaining states of the country. Sen (1997) calculates the tax effort index of various categories of taxes for 15 major states in India for the period 1991-92 to 199394. His analysis shows that tax effort varies across states and there is no apparent correlation between level of development and tax effort.

Bajpai and Sachs (1999) find that a reform of the state fiscal system is necessary in order to reduce expenditures and increase revenues. They found that inefficient intergovernmental transfer mechanisms in India are responsible for fiscal indiscipline at the state level.

Their review reveals that the existing studies have been confined to the amount of the fiscal devolution and its effectiveness in eliminating horizontal and vertical inequalities. A serious analysis of the evolution of criteria of fiscal devolution has been missing. In this paper we will

\footnotetext{
${ }^{1}$ Taxable capacity refers to the predicted tax-to-gross-domestic-product ratio that can be estimated empirically, taking into account a country's specific macroeconomic, demographic, and institutional features, which all change through time. Tax effort is defined as an index of the ratio between the share of the actual tax collection in gross domestic product and taxable capacity. The use of tax effort and actual tax collection benchmarks allows the ranking of countries into four different groups: low tax collection, low tax effort; high tax collection, high tax effort; low tax collection, high tax effort; and high tax collection, low tax effort (Le, Moreno-Dodson, and Bayraktar 2012).
} 
take up the critical analysis of the criteria of devolution and examine the plausibility of integrating a gender component in the formula.

\section{EVOLUTION OF THE TAX DEVOLUTION FORMULA}

Since 1951, fourteen finance commissions (FC) have submitted their reports to the government. The FCs have used different formulas for the inter se devolution of each states' share of central tax revenue. However, the approaches used by the fourteen FCs can be categorized into three distinct phases. The first seven FCs used different distribution formulas for determining the devolution of the income tax shares and union excise duties. This was the case because Article 270 of the constitution had provided for mandatory sharing of income tax while Article 272 had provided for sharing of the union excise duties at the discretion of the central government. Population and collection and assessment of taxes were the only two criteria used by the first seven FCs for determining the inter se shares of the states in the case of income tax (table 1). However, the criteria used for the devolution of union excise duties evolved over time.

Table 1: Inter se Sharing of Income Tax

\begin{tabular}{|l|r|r|}
\hline \multirow{2}{*}{ Finance Commission } & \multicolumn{2}{|c|}{ Weigh (in percent) } \\
\cline { 2 - 3 } & Population & Collection \\
\hline First, Third, and Fourth & 80 & 20 \\
\hline Second & 90 & 10 \\
\hline & Population & Assessment \\
\hline Fifth, Sixth, and Seventh & 90 & 10 \\
\hline
\end{tabular}

Source: Finance Commission Reports

Population continued to be the largest determining factor up to Sixth FC, but its share declined from 100 to 75 percent. The Seventh FC drastically reduced the weight given to population to 25 percent (table 2). Also, the changing nature of the criteria used indicates that there was greater emphasis on factors related to economic backwardness and fiscal weakness of the states. 
Table 2: Inter se Sharing of Union Excise Duties

\begin{tabular}{|l|r|l|l|l|}
\hline \multirow{2}{*}{$\begin{array}{l}\text { Finance } \\
\text { Commission }\end{array}$} & \multicolumn{4}{|c|}{ Relative Weights (Percent) } \\
\cline { 2 - 5 } & Population & \multicolumn{2}{|c|}{ Other Factors } & \\
\hline First & 100 & & & \\
\hline Second & 90 & 10 & & \\
\hline Third & 80 & $\begin{array}{l}20 \text { (social and economic } \\
\text { backwardness) }\end{array}$ & \\
\hline Fourth & $80+16.66^{*}$ & 3.33 (index of backwardness) & & \\
\hline Fifth & 75 & 25 (income distance) & & \\
\hline Sixth & \multicolumn{2}{|r|}{ weights unspecified } & Poverty & $\begin{array}{c}\text { Revenue } \\
\text { Equalization }\end{array}$ \\
\hline & 25 & & 25 & \\
\hline Seventh & Inverse of per Capita Income & 25 \\
\hline
\end{tabular}

Source: Finance Commission Reports

From the Eighth FC onwards there was a move towards unifying the formula for the inter se distribution of both income tax and union excise duties. The weight accorded to population was reduced drastically, ranging between 20 percent to a little less than 30 percent for the Eighth through Tenth FCs (table 3).

The Tenth FC also recommended an "alternative scheme of devolution," whereby, after a constitutional amendment, proceeds of all federal taxes were to be shared with the state governments. The alternative scheme was accepted by the central government and implemented through the 80th constitutional amendment. 
Table 3: Criteria for Fiscal Devolution: Eighth, Ninth, and Tenth Finance Commission

\begin{tabular}{|c|c|c|c|c|c|c|c|c|}
\hline \multicolumn{9}{|c|}{ Relative Weights (Percent) } \\
\hline FC & Population & Contribution & $\begin{array}{c}\text { Inverse of } \\
\text { per capita } \\
\text { Income } \\
\text { Multiplied } \\
\text { by } \\
\text { Population } \\
\end{array}$ & $\begin{array}{c}\text { Distance } \\
\text { of per } \\
\text { capita } \\
\text { Income }\end{array}$ & $\begin{array}{c}\text { Composite } \\
\text { Index of } \\
\text { Backwardness }\end{array}$ & $\begin{array}{c}\text { Tax } \\
\text { Effort }\end{array}$ & Area & $\begin{array}{l}\text { Infra } \\
\text { Index }\end{array}$ \\
\hline Eighth & 22.5 & 10 & 22.5 & 45 & & & & \\
\hline Ninth & 22.5 & 10 & 11.25 & 45 & 11.25 & & & \\
\hline Tenth & 20.0 & & & 60 & & 10 & 5 & 5 \\
\hline
\end{tabular}

Source: Finance Commission Reports

The criteria followed by the Eleventh FC onwards are broadly reflective of four considerations:

i) vertical transfers; (ii) horizontal equity; (iii) incentives for efficiency; and (iv) cost

disadvantages. Two core criteria have been used by the FCs for horizontal equity: income distance and inverse-income formula.

Table 4: Criteria for Fiscal Devolution: Eleventh, Twelfth, and Thirteenth Finance Commission

\begin{tabular}{|l|r|r|r|r|r|r|r|}
\hline \multirow{2}{*}{ FC } & \multicolumn{7}{|c|}{ Relative Weights (Percent) } \\
\cline { 2 - 8 } & $\begin{array}{c}\text { Population } \\
\text { (1971) }\end{array}$ & Tax Effort & $\begin{array}{c}\text { Income } \\
\text { Distance }\end{array}$ & Area & $\begin{array}{c}\text { Infra } \\
\text { Index }\end{array}$ & $\begin{array}{c}\text { Fiscal } \\
\text { Discipline }\end{array}$ & $\begin{array}{c}\text { Fiscal } \\
\text { Capacity } \\
\text { Distance }\end{array}$ \\
\hline Eleventh & 10 & 5.0 & 62.5 & 7.5 & 7.5 & 7.5 & \\
\hline Twelfth & 25 & 7.5 & 50.0 & 10.0 & & 7.5 & \\
\hline Thirteenth & 25 & & & 10.0 & & 17.5 & 47.5 \\
\hline
\end{tabular}

Source: Finance Commission Reports

The Eleventh FC accorded a weight of 75 percent to these two core criteria. Cost variations are brought into consideration through the criteria based on area and existing infrastructure: the larger the area (per crore population), the higher the per capita cost. Similarly, the lower the index of infrastructure, the higher the per capita cost will be. Fiscal discipline ${ }^{2}$ was also made one of the criteria for the first time by the Eleventh FC and its share was increased sharply from 7.5 percent to 17.5 percent by the Thirteenth FC. A new measure of resource deficiency was

\footnotetext{
${ }^{2}$ Fiscal discipline measures the improvement in the performance of each state during the time period $2005-06$ to 2007-08 relative to the base years of 2001-02 to 2003-04 in terms of the ratio of its own revenue receipts to total revenue expenditure, as compared with the average ratio across all states.
} 
introduced by the Thirteenth FC - fiscal capacity distance. It was accorded the highest weight of 47.5 percent (table 4$)$.

The Fourteenth FC made some major changes in the inter se sharing of tax revenue to states. The commission recognized the changing demographic realities and provided space for the demographic changes across the states in the last forty years. Accordingly, the relative share of the states in the population according to 2011 census was given a weight of 10 percent.

The Fourteenth FC also recognized the ecological benefits as well as cost disadvantages that come with forested areas. To incentivize states to promote and preserve their forested areas, as well as to compensate them for this cost disadvantage, it has been introduced as an indicator (for the first time) with a weight of 7.5 percent.

As can be seen, the tax devolution formulas used by the different FCs have evolved over time according to the needs of the situation. The devolution formulas as adopted over time have reduced the weight on fiscal need indicators (like population), increased the weight for measures of equity, and introduced some measure of fiscal efficiency. Income distance criteria ${ }^{3}$ was used for the first time by the Eighth FC to make the transfers more equitable. Similarly, criteria such as tax effort, the infrastructure index, and fiscal discipline were used by different commissions to incentivize states to better use the resources already at their disposal and to enhance their efficiency. The Fourteenth FC also introduced new indicators to take into account demographic and environmental changes.

The concept of development is now more comprehensive and non-material dimensions like education, health, and access to basic amenities are increasingly becoming more important. There are states (such as Gujarat and Punjab) with high per capita income, but they perform poorly when it comes to education and health. It is imperative for the future FCs to take a broader dimension of human development into consideration while devolving funds to states.

\footnotetext{
${ }^{3}$ Fiscal capacity (income) distance measures the distance of the estimated potential per capita tax revenue of each state using different weighted average tax ratios for general and special category states from that of Haryana, which ranks second under this criterion.
} 
Some measure of human development, such as the human development index (HDI), can be used to devolve funds, incentivizing states to improve the provisioning of basic amenities to their citizens.

The criteria used by various Finance Commissions for the inter-se distribution of tax shares across the states have changed over time. However, these criteria could be broadly classified as: a) factors reflecting needs, such as population and area; b) revenue disability measures, such as fiscal capacity distance and per capita income distance from the highest per capita income or inverse of it; c) cost disability indicators, such as forested area; and d) fiscal efficiency indicators, such as tax effort and fiscal discipline. While the weight assigned to population has declined considerably, weights assigned to income distance and efficiency factors have increased.

The report of the Finance Commission, as laid out in its terms of reference (ToR), has expanded over the years but concerns arising out of gender inequality have never been a part of its ToR. This has happened in spite of the growing realization that it is necessary to deal with gender inequality issues with respect to fiscal decentralization. Fiscal decentralization got a major push in 1992 when the government passed the 73rd and 74th constitutional amendments, giving constitutional status to the rural local bodies and urban local bodies, in both the letter and spirit of the law, in order to bring about greater decentralization and increase the involvement of the community in planning and implementing schemes and, thus, increase accountability. The most revolutionary provision is the reservation of one-third of the seats in local bodies for women. However, the same enthusiasm has not been shown when it comes to setting the ToR for the FCs, which takes into account modern challenges to the country. Consequently, none of the FCs set up so far have looked at the problem of tax devolution through the lens of gender inequality.

The Fourteenth FC submitted its report on February 24, 2015. The key highlight of the commission's recommendation was to devolve an unprecedented 42 percent of the divisible pool of taxes to the states during the period from 2015-16 to 2019-20, against the 32 percent 
suggested by the previous commissions. The formula suggested for the inter se devolution of this divisible pool is given in the table below.

Table 5: Criteria of Fiscal Devolution: Fourteenth Finance Commission

\begin{tabular}{|l|r|}
\hline Indicators & Weight (in percent) \\
\hline Total Population (1971) & 17.5 \\
\hline Demographic Change & 10.0 \\
\hline Area & 15.0 \\
\hline Forest Area & 7.5 \\
\hline Income Distance & 50.0 \\
\hline \multicolumn{2}{|l}{ Source: Fourteenth Finance Commission Report }
\end{tabular}

The Fourteenth FC recognized the changing demographic realities and provided a space for the demographic changes in the last forty years across states to be taken into consideration when deciding on the devolution. To capture the demographic changes since 1971, both in terms of migration and age structure, the commission assigned a 10 percent weight to the 2011 population. The income distance has been calculated as per the method of the Twelfth FC (see footnote 3). A three-year average (2010-11 to 2012-13) per capita comparable gross state domestic product (GSDP) has been taken for all 29 states. Income distance has been computed by taking the distance from the state having highest per capita GSDP. In this case, Goa has the highest per capita GSDP, followed by Sikkim. Since these two are very small states, adjustments are needed to avoid distortions and hence income distance has been computed from the state with the third-highest per capita GSDP — Haryana — and Goa, Sikkim, and Haryana have been provided the same distance as obtained for the Haryana.

\subsection{Introducing Gender Sensitivity into the Tax Devolution Formula}

Our next focus is to see if the tax devolution formula continues to remain progressive if we introduce some criteria to capture gender inequality. We select the child sex ratio index for girls ages 0-6 years as a proxy for gender inequality and include it as one of the indicators for tax devolution (that is the number of girls as compared to boys in the 0-6 age cohort is adopted as the basis for determining the states' relative shares of the amount to be disbursed by applying the allotted weight). The new formula is presented below. 
Table 6: Inter-se Share of States: As per New Proposed Formula

\begin{tabular}{|l|r|}
\hline Indicators & $\begin{array}{c}\text { Weight (in } \\
\text { percent) }\end{array}$ \\
\hline Total Population (1971) & 17.5 \\
\hline Demographic Change & 5.0 \\
\hline Child Sex Ratio Index (0-6 Years) & 5.0 \\
\hline Area & 15.0 \\
\hline Forest Area & 7.5 \\
\hline Income Distance & 50.0 \\
\hline
\end{tabular}

Source: Authors' compilation

The central idea behind this inclusion is to reward those states with a high child sex ratio ${ }^{4}$ and provide them additional funds based on this indicator so that they can continue to take measures to improve gender equality. Also, the correlation between the child sex ratio and below-poverty line ratio for these 29 states turns out to be 0.33 (i.e., poor states have a better child sex ratio). Thus, inclusion of the child sex ratio as one of the indicators rewards poorer states.

The child sex ratio has been calculated in the following way: First we compute the difference between the child sex ratios of a given state with Arunachal Pradesh (which has highest child sex ratio). Next we take the inverse of the difference as calculated in the earlier step. Since the child sex ratio for Chhattisgarh, Meghalaya, and Mizoram are very close to that of Arunachal Pradesh, their inverse is very high. Hence, adjustments are needed to avoid distortions. Consequently, these states are provided the same value as that of Kerala, which is the next-best performing state. Arunachal Pradesh is also provided with the same value.

\section{FISCAL TRANSFERS: INTER-SE SHARE OF STATES}

This section presents the inter-se share of the states ex post to integrating the gender variable in the devolution formula. Based on this new formula, we devolve funds to the states and calculate

\footnotetext{
${ }^{4}$ In India, the child sex ratio is defined as the number of females per thousand males in the age group 0-6 years old in the total population. Thus, it is equal to 1,000 times the reciprocal of the sex ratio (ratio of males to females in the population), therefore a high child sex ratio is a positive outcome.
} 
their respective shares. The table 7 shows the changes in the inter-se shares of the states and the ranks of states if we change the fund devolution formula. The biggest beneficiaries, in terms of share, are Arunachal Pradesh and Mizoram. The share of both these states goes up by 0.46 percent. Meghalaya and Chhattisgarh's shares also go up by 0.45 and 0.36 percent, respectively. All these states have performed very well in terms of their child sex ratio, which helped them improve their share. Uttar Pradesh, on the other hand, is the biggest loser in this change in formula. Its share in tax devolution goes down by 0.79 percentage points. Maharashtra (-0.42) and Bihar (-0.34) are the next two big losers. This loss is on two accounts: (a) a poor record in terms of their child sex ratio; and (b) a reduction in the weight of demographic change. 
Table 7: Inter-se Share of States: As per Fourteenth FC's Existing Formula

\begin{tabular}{|c|c|}
\hline State & $\begin{array}{l}\text { Share } \\
\text { (in percent) }\end{array}$ \\
\hline Andhra Pradesh & 4.305 \\
\hline Arunachal Pradesh & 1.370 \\
\hline Assam & 3.311 \\
\hline Bihar & 9.665 \\
\hline Chhattisgarh & 3.080 \\
\hline Goa & 0.378 \\
\hline Gujarat & 3.084 \\
\hline Haryana & 1.084 \\
\hline Himachal Pradesh & 0.713 \\
\hline Jammu \& Kashmir & 1.854 \\
\hline Jharkhand & 3.139 \\
\hline Karnataka & 4.713 \\
\hline Kerala & 2.500 \\
\hline Madhya Pradesh & 7.548 \\
\hline Maharashtra & 5.521 \\
\hline Manipur & 0.617 \\
\hline Meghalaya & 0.642 \\
\hline Mizoram & 0.460 \\
\hline Nagaland & 0.498 \\
\hline Odisha & 4.642 \\
\hline Punjab & 1.577 \\
\hline Rajasthan & 5.495 \\
\hline Sikkim & 0.367 \\
\hline Tamil Nadu & 4.023 \\
\hline Telangana & 2.437 \\
\hline Tripura & 0.642 \\
\hline Uttar Pradesh & 17.959 \\
\hline Uttarakhand & 1.052 \\
\hline West Bengal & 7.324 \\
\hline All States & 100.000 \\
\hline
\end{tabular}

Source: Fourteenth Finance Commission Report

In terms of ranks, Meghalaya and Mizoram are the biggest gainers, both moving up by four places. Chhattisgarh also moves up by four places. On the other hand, the rank of Himachal Pradesh deteriorates by three places. However, the share of Himachal Pradesh in tax devolution goes up from 0.71 percent to 0.74 percent. 
Table 8: Inter-se Share of States: As per New Fourteenth FC g-Formula

\begin{tabular}{|c|c|c|c|c|c|c|}
\hline \multirow[b]{2}{*}{ States } & \multicolumn{3}{|c|}{ Share } & \multicolumn{3}{|c|}{ Rank } \\
\hline & $\begin{array}{l}\text { 14th } \\
\text { FC }\end{array}$ & $\begin{array}{l}\text { New g- } \\
\text { Formula }\end{array}$ & $\begin{array}{l}\text { Improvement(+)/ } \\
\text { Deterioration (-) }\end{array}$ & $\begin{array}{l}\text { 14th } \\
\text { FC }\end{array}$ & $\begin{array}{l}\text { New g- } \\
\text { Formula }\end{array}$ & $\begin{array}{c}\text { Improvement(+)/ } \\
\text { Deterioration (-) }\end{array}$ \\
\hline Andhra Pradesh & 6.75 & 6.50 & -0.24 & 5 & 5 & 0 \\
\hline $\begin{array}{l}\text { Arunachal } \\
\text { Pradesh }\end{array}$ & 1.37 & 1.83 & 0.46 & 18 & 17 & 1 \\
\hline Assam & 3.31 & 3.55 & 0.24 & 11 & 11 & 0 \\
\hline Bihar & 9.67 & 9.34 & -0.34 & 2 & 2 & 0 \\
\hline Chhattisgarh & 3.08 & 3.44 & 0.36 & 14 & 12 & 2 \\
\hline Goa & 0.37 & 0.49 & 0.12 & 27 & 28 & -1 \\
\hline Gujarat & 3.09 & 2.88 & -0.21 & 13 & 14 & -1 \\
\hline Haryana & 1.03 & 0.95 & -0.08 & 20 & 21 & -1 \\
\hline $\begin{array}{l}\text { Himachal } \\
\text { Pradesh }\end{array}$ & 0.71 & 0.74 & 0.03 & 21 & 24 & -3 \\
\hline $\begin{array}{l}\text { Jammu \& } \\
\text { Kashmir }\end{array}$ & 1.86 & 1.84 & -0.02 & 16 & 16 & 0 \\
\hline Jharkhand & 3.14 & 3.16 & 0.02 & 12 & 13 & -1 \\
\hline Karnataka & 4.72 & 4.61 & -0.10 & 8 & 8 & 0 \\
\hline Kerala & 2.50 & 2.83 & 0.32 & 15 & 15 & 0 \\
\hline $\begin{array}{l}\text { Madhya } \\
\text { Pradesh }\end{array}$ & 7.55 & 7.32 & -0.24 & 3 & 3 & 0 \\
\hline Maharashtra & 5.52 & 5.10 & -0.42 & 6 & 7 & -1 \\
\hline Manipur & 0.62 & 0.71 & 0.09 & 24 & 25 & -1 \\
\hline Meghalaya & 0.64 & 1.09 & 0.45 & 23 & 19 & 4 \\
\hline Mizoram & 0.46 & 0.92 & 0.46 & 26 & 22 & 4 \\
\hline Nagaland & 0.50 & 0.62 & 0.12 & 25 & 26 & -1 \\
\hline Odisha & 4.65 & 4.59 & -0.06 & 9 & 9 & 0 \\
\hline Punjab & 1.58 & 1.49 & -0.09 & 17 & 18 & -1 \\
\hline Rajasthan & 5.50 & 5.26 & -0.24 & 7 & 6 & 1 \\
\hline Sikkim & 0.37 & 0.61 & 0.25 & 28 & 27 & 1 \\
\hline Tamil Nadu & 4.02 & 3.85 & -0.17 & 10 & 10 & 0 \\
\hline Tripura & 0.64 & 0.87 & 0.23 & 22 & 23 & -1 \\
\hline Uttar Pradesh & 17.98 & 17.19 & -0.79 & 1 & 1 & 0 \\
\hline Uttarakhand & 1.05 & 1.05 & 0.00 & 19 & 20 & -1 \\
\hline West Bengal & 7.33 & 7.18 & -0.15 & 4 & 4 & 0 \\
\hline
\end{tabular}

Source: Authors' computations 
The rank of Himachal Pradesh has gone down because the share of states that were ranked below it, such as Meghalaya and Mizoram, have seen a bigger improvement in their share in tax devolution. The comparative perspectives of the existing and new g-formula of the Fourteenth FC are given in table 9.

Table 9: Comparative Perspective: Existing and New g-Formula of Fourteenth FC

\begin{tabular}{|c|c|c|c|}
\hline \multirow[t]{2}{*}{ States } & \multicolumn{2}{|c|}{ Rank } & \\
\hline & $\begin{array}{c}\text { Fourteenth } \\
\text { FC }\end{array}$ & $\begin{array}{c}\text { New } \\
\text { g-Formula }\end{array}$ & $\begin{array}{c}\text { Improvement(+)/ } \\
\text { Deterioration (-) }\end{array}$ \\
\hline Andhra Pradesh & 5 & 5 & 0 \\
\hline Arunachal Pradesh & 18 & 17 & 1 \\
\hline Assam & 11 & 11 & 0 \\
\hline Bihar & 2 & 2 & 0 \\
\hline Chhattisgarh & 14 & 12 & 2 \\
\hline Goa & 27 & 28 & -1 \\
\hline Gujarat & 13 & 14 & -1 \\
\hline Haryana & 20 & 21 & -1 \\
\hline Himachal Pradesh & 21 & 24 & -3 \\
\hline Jammu \& Kashmir & 16 & 16 & 0 \\
\hline Jharkhand & 12 & 13 & -1 \\
\hline Karnataka & 8 & 8 & 0 \\
\hline Kerala & 15 & 15 & 0 \\
\hline Madhya Pradesh & 3 & 3 & 0 \\
\hline Maharashtra & 6 & 7 & -1 \\
\hline Manipur & 24 & 25 & -1 \\
\hline Meghalaya & 23 & 19 & 4 \\
\hline Mizoram & 26 & 22 & 4 \\
\hline Nagaland & 25 & 26 & -1 \\
\hline Odisha & 9 & 9 & 0 \\
\hline Punjab & 17 & 18 & -1 \\
\hline Rajasthan & 7 & 6 & 1 \\
\hline Sikkim & 28 & 27 & 1 \\
\hline Tamil Nadu & 10 & 10 & 0 \\
\hline Tripura & 22 & 23 & -1 \\
\hline Uttar Pradesh & 1 & 1 & 0 \\
\hline Uttarakhand & 19 & 20 & -1 \\
\hline West Bengal & 4 & 4 & 0 \\
\hline
\end{tabular}

Source: Fourteenth Finance Commission Report (basic data) 


\section{IS A GENDER-INCLUSIVE FISCAL DEVOLUTION FORMULA PROGRESSIVE?: AN ECONOMETRIC ANALYSIS}

As a prelude, we check to see if the formula as suggested by the Fourteenth FC is progressive or not; that is, whether states with a lower per capita GSDP are likely to receive, on average, much larger transfers per capita or not. To check this we run a cross-sectional regression for 20 major states with the log of per capita tax devolution as the dependent variable and the log of per capita GSDP as the independent variable. The regression model is as follows:

$\ln \_$pct $=\beta_{1}+\beta_{2} * \ln \_$pcy

where:

$\ln \_$pct $=\log$ of per capita fund transfer to a state

$\ln \_$pcy $=\log$ of per capita GSDP of a state

The $\beta_{2}$ turns out to be -0.44 and is statistically significant at the 5 percent level. Thus, a 1 percent increase in per capita GSDP leads to a -0.44 percent reduction in per capita tax devolution to the states.

Subsequently, we check to see if the tax devolution based on this new formula (integrating gender) is progressive or not. As we did before, we run a cross-sectional regression for the 20 states and find that the coefficient of the log of per capita fund transfer with respect to the log of per capita GSDP is -0.46 . It also turns out to be statistically significant at 5 percent level. 
Table 10: Regression Result for the Fourteenth FC Formula

\begin{tabular}{|l|c|c|}
\hline Independent Variable & $\begin{array}{c}\text { Fourteenth FC } \\
\text { Formula }\end{array}$ & New g-Formula \\
\hline log_pcgsdp & $-0.44^{*}$ & $-0.46^{*}$ \\
\hline _constant & $13.40^{*}$ & $13.60^{*}$ \\
\hline Adj. ${ }^{2}$ & 0.29 & 0.25 \\
\hline
\end{tabular}

Note: (1) log of per capita fund transfer is the dependent variable

(2) $\log \_$pcgsdp $=$log of per capita GSDP

(3) * Significant at 5\% level

(4) Regression result is based on 20 major states

Source: Authors' computations

Notice that the degree of progressivity has increased mildly with the inclusion of the child sex ratio as an indicator, and the coefficient of the log of per capita fund transfer improves from -0.44 to -0.46 .

Figure 1: Fund Devolution as per New g-Formula

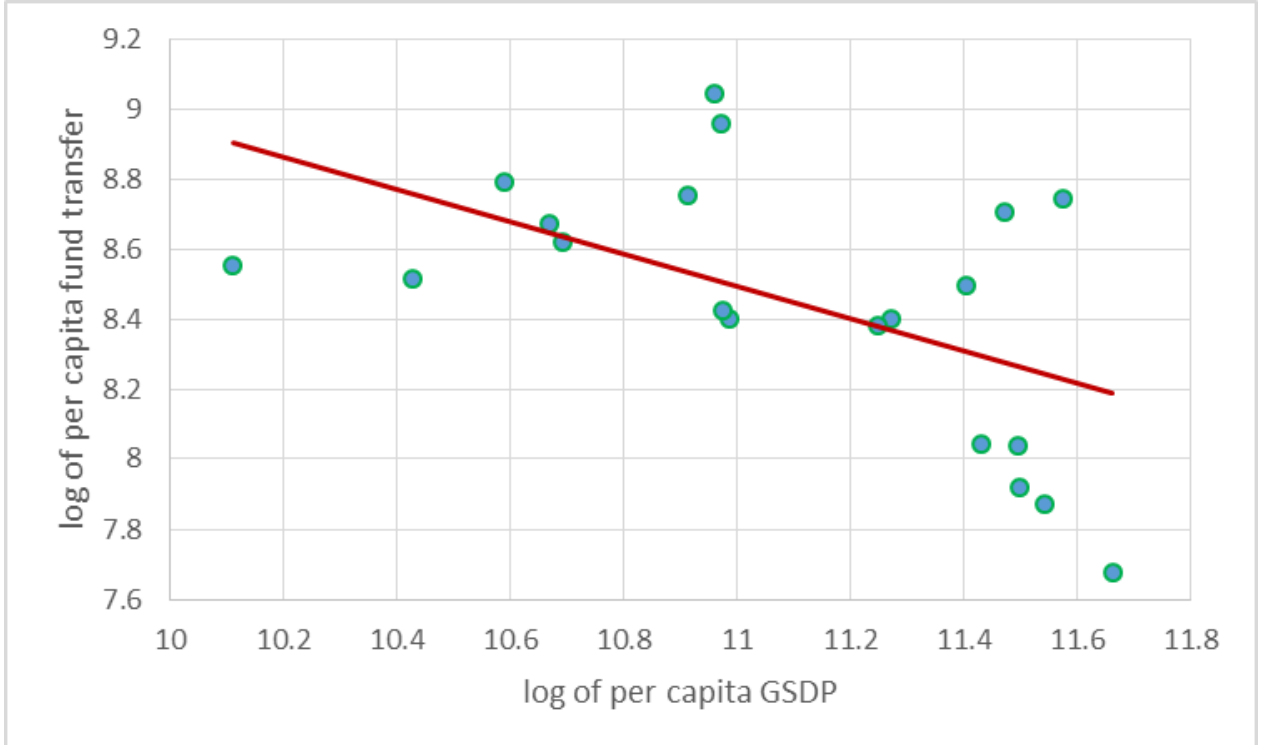

Source: Finance Commission (various years) 
We also check the impact of tax devolution on income inequality based on the two new formulas. To do this we look at three variables:

(1) Per capita GSDP

(2) Per capita income_ $14^{\text {th }} \mathrm{FC}$ : the sum of per capita income GSDP and per capita fund transfer according to the Fourteenth FC formula

(3) Per capita income_new formula: the sum of per capita GSDP and per capita fund transfer according to the alternative formula.

We calculate the value of these three variables for 20 major states. Next we calculate the standard deviation for these three variables, as shown in table 11.

Table 11: Standard Deviation of Variables for 20 Major States

\begin{tabular}{|l|r|}
\hline Variable & Standard Deviation \\
\hline per capita GSDP & 27414 \\
\hline per capita GSDP_14th FC & 26526 \\
\hline per capita GSDP_new formula & 26521 \\
\hline
\end{tabular}

Source: Authors' computations

As can be seen, the standard deviation of the variable "per capita GSDP_new formula" is lower than that of "per capita GSDP_14th FC," which implies that the devolution of funds on the basis of the alternative formula leads to less inequality among states as compared to fund devolution on the basis of the Fourteenth FC formula.

\section{CONCLUSION}

The analysis revealed that integrating a gender variable (child sex ratio) as one of the criteria for intergovernmental fiscal devolution has four advantages. One, it incentivizes states to improve gender inequality. Two, it makes the fund transfer more progressive, as the coefficient of the log of per capita income improves from -0.44 to -0.46 . Three, it also benefits the poorer states, as the 
correlation between the child sex ratio and below-poverty line ratio is 0.33 , i.e., poorer states have a better child sex ratio. Finally, it makes the per capita income across states, post devolution, more equitable, as is evident from the standard deviation. 


\section{REFERENCES}

Bajpai, N., and J.D. Sachs. 1999. "The State of State Government Finances in India." Development Discussion Paper No. 719. Cambridge, MA: Harvard Institute for International Development.

Chakraborty, L. 2010. “Determining Gender Equity in Fiscal Federalism: Analytical Issues and Empirical Evidence from India.” Levy Institute Working Paper No. 590. Annandale-onHudson, NY: Levy Economics Institute of Bard College.

Chakraborty, P. 2003. "Unequal Fiscal Capacities across Indian States: How Corrective is the Fiscal Transfer Mechanism?" Paper prepared for the UNU/WIDER Project Conference on Spatial Inequality in Asia, UNU Centre, Tokyo, March 28-29.

Coondoo D., A. Majumdar, R. Mukherjee, and C. Neogi. 2001. "Relative tax performance analysis for selected states in India.” Economic and Political Weekly 36(40): 3869-71.

Garg, S., A. Goyal, and R. Pal. 2014. "Why Tax Effort Falls Short of Capacity in Indian States: A Stochastic Frontier Approach.” IGIDR Working Paper WP-032-2014. Mumbai: Indira Gandhi Institute of Development Research.

Government of India (GoI). 2014-15. Economic Survey of India. New Delhi: Ministry of Finance.

. 2015. Report of the Fourteenth Finance Commission. New Delhi: Ministry of Finance.

. 2009. Report of the Thirteenth Finance Commission. New Delhi: Ministry of Finance.

2004. Report of the Twelfth Finance Commission. New Delhi: Ministry of Finance.

Le, T.M., B. Moreno-Dodson, and N. Bayraktar. 2012. "Tax Capacity and Tax Effort Extended Cross-Country Analysis from 1994 to 2009.” World Bank Policy Research Working Paper 6252. Washington, DC: The World Bank.

Nirmal, A. 2004. "Study on Transfer of Resources from Centre to States (1978-79 to 2002-03)." Mospi-seminar series, November. New Delhi: Government of India.

Oates, W.E. 2005. “Toward a Second-Generation Theory of Fiscal Federalism.” International Tax and Public Finance 12: 349-73.

Oommen, M.A 2004. Fiscal Decentralisation to Rural Governments, Volume IV - Kerala Case Study.. New Delhi: World Bank Rural Development Unit. 
Rao, M.G. 2003. "Incentivising Fiscal Transfers in the Indian Federation." Journal of Federalism 33(4): 43-62.

_ 2002. "State Finances in India: Issues and Challenges." Economic and Political Weekly 37(31): 3261-71.

Sen, T.K. 1997. "Relative Tax Effort by Indian States.” NIPFP Working Papers No. 5. New Delhi: National Institute of Public Finance and Policy.

Singh, N. 2004. "India's System of Intergovernmental Fiscal Relations." Paper presented at the 10th Anniversary Conference of the Financial and Fiscal Commission of South Africa, August 10-12, Cape Town, South Africa.

Singh, N., and T.N. Srinivasan. 2006. "Federalism and economic development in India: An assessment.” MPRA Paper 12452. Munich: University Library of Munich (revised August 2008).

Weingast, B.R. 2006. "Second Generation Fiscal Federalism: Implications for Decentralized Democratic Governance and Economic Development." Discussion Draft. Munich: Center for Economic Studies and Ifo Institute for Economic Research (CESifo). Available at: http://www.ifigr.org/workshop/IFIR-CESifo/papers/weingast.pdf 